\title{
UDC 130.2:821.161.2.02
}

\author{
Z. O. YANKOVSKA ${ }^{1^{*}}$, L. V. SOROCHUK ${ }^{2 *}$ \\ ${ }^{1 *}$ The National University of Ostroh Academy (Ostroh, Ukraine), e-mail zanna.malva@gmail.com, \\ ORCID 0000-0002-7846-2796 \\ ${ }^{2 *}$ Taras Shevchenko National University of Kyiv (Kyiv, Ukraine), e-mail LVS1166@ukr.net, ORCID 0000-0003-0478-356X
}

\section{Anthropological Dimension of the Philosophical "Literature-Centric" Model of Ukrainian Romanticism}

Purpose. Romanticism as a movement developed in Germany, where, becoming the philosophy of time in the 18th-19th centuries, spread to all European countries. The "mobility" of the Romantic doctrine, its diversity, sometimes contradictory views, attitude to man as a free, harmonious, creative person led to the susceptibility of this movement by ethnic groups, different in nature and mentality. Its ideas found a wide response in Ukraine with its "cordocentric" type of culture in the early nineteenth century. Since the peculiarity of "Ukrainian Romanticism" was its "literary-centric" nature, the purpose of this study is to analyse and comprehend the place of man in the national philosophy and literature of this period. Accordingly, the main tasks of the work are as follows: to determine the main features, the nature of Ukrainian Romanticism; to trace the main vectors of comprehension and image of man in the literature of this time. Theoretical basis. The ideas of European Romanticism (as a philosophical-historical and general cultural movement) were creatively rethought and assimilated during the emergence of new Ukrainian literature. It provided samples of highly artistic works, unique names of talented writers - creators and thinkers, who in their works reflected the philosophy of time. Based on the works of F. Schlegel, partly E. Husserl, M. Heidegger, K. Jaspers, Romanticism in the Ukrainian humanities, in terms of philosophy, culturology, as well as at the intersection with literature, was studied by T. Bovsunivska, Y. Hrybkova, S. Efremov, N. Kalenichenko, S. Kozak, T. Komarynets, D. Nalyvayko, Y. Nakhlik, I. Ogorodnyk, V. Ogorodnyk, A. Sinitsyna, D. Chyzhevsky, M. Yatsenko, E. Kyryliuk, M. Biletsky, D. Dontsov, S. Efremov, G. Kostyuk, S. Krymsky, Y. Sherekh and others. Originality. The authors of the article prove that Romanticism in Ukraine, being "literary-centric" inherently, having absorbed the main ideas and features of European Romanticism, has its own features and vectors of formation and development. Man in this kind of movement, thanks to the means of art, appears very clearly as a spiritually rich, sensitive, vulnerable and strong person. For him or her, the highest value is freedom, the ability to make freely independent fateful decisions. Conclusions. Ukrainian writers, reflecting the philosophical ideas of Romanticism, saw in man a harmonious combination of "natural" and "social", through which he indirectly carries out his own national existence. In addition to the objective realities of the external world, in their works, Romantic writers appeal to the subjective, internal, spiritual, "ideal" world of the hero, who interacts with reality through his own system of values. At each level of development of the humanities and methodology of cognition, this allows a new reading of these works.

Keywords: man; personality; spirituality; Romanticism; "literary-centric" model of Ukrainian Romanticism; freedom

\section{Introduction}

The beginning of the 19th century in philosophical science was marked by new approaches to the philosophical understanding of reality, dominated by humanistic tendencies, irrationalism (as opposed to Enlightenment rationalism), anthropocentrism and subjectivism.

Romanticism as a philosophy and ideology of time, born in Germany, flooded Europe in the 18th century and spread in Ukraine in the early 19th century. The joint work of the brothers August and Friedrich Schlegel, the activities of the representatives of the Jena Romantic circle, led by F. Schlegel, counterposed their modern thinking and ideology to "classical" and ancient philosophy. The ideal of man (idealism) in German classical philosophy is a "free, integrated harmonious personality" (Bohutskyi, Andrushchenko, Bezvershuk, \& Novokhatko, 2007, p. 205). In the 19th century, when Romanticism (as a movement) spread in Ukraine, it, based on fairly wellestablished principles, still takes on some other forms and colours, is modified. It is clear that the 
formation of the Romantic worldview was greatly influenced by the German idealist philosophy, according to which, as M. Yatsenko (2005) noted, "the world (universe) is a living dynamic whole, in constant motion and change, in the struggle of contradictions, which in the synthesis act as its wealth" (authors' transl.) (p. 235). Romanticism became not just a denial of the old, but a response to the events and ideology of time. W. Busch wrote in this regard:

Romanticism is rightly considered a reaction to the decisive turn of the

New Age, the Great French Revolution, and especially the defeat of its absolute claims. It becomes in literature and art history a sign of a completely new phenomenon, which in its later conservative form will be seen as the antipode to everything classic. (authors' transl.) (Original quote: "Die Romantik, zu Recht verstanden als Reaktion auf den entscheidenden Einschnitt der Neuzeit, die Französische Revolution, besonders aber das Scheitern ihrer absoluten Ansprüche, wird in der Literatur - wie der Kunstgeschichte als das schlechthin Neue begriffen, das selbst in seiner späteren konservativen Ausprägung als antipodisch zu allem Klassischen gesehen wird"). (Busch, 1999, p. 39)

At this time, S. Kierkegaard, arguing with the Romantics about the concept of irony as "open dynamics of the world and knowledge" and turning to the "Socratic" irony "as an alternative", developed existentialism, which actualized the understanding of human existence as a unique spiritual person able to make a fateful choice and to be responsible for it, whatever the choice. V. Stetsenko (2010), analysing the works of the scientist, noted that for him "existence is the core of the human "Self", thanks to which the "Self" appears not just as a separate empirical individual and not as a "thinking mind" [...], but as a specific unique personality" (authors' transl.) (p. 47).

The teachings of S. Kierkegaard were continued by F. Nietzsche, W. Dilthey, A. Bergson, E. Husserl, M. Heidegger, K. Jaspers, A. Camus, J.-P. Sartre and others. In the semantic field of existentialism, they raised the problems of subjectivity and individualism, which are also inherent in romanticism. According to I. Malyshivska and O. Trotsenko (2018), "the basis of existentialism is the problem of human existence, his inner world and the personal crisis in which he found himself" (authors' transl.) (p. 222). Man rethinks his own being and himself in this being. Existentialists considered freedom to be the greatest value in human life. According to them, its loss ("drama of freedom") causes tragic consequences. Therefore, in the period of the rise and development of Romanticism "the leading problem is the tragic fate of man, the cult of mental suffering, the sharp opposition to dream, ideal and reality" (Yatsenko, 2005, p. 237), which are the features of existentialism. 
Already A. Camus and J.-P. Sartre embodied this understanding of human existence in works of art, seeking to show and understand the reasons for the unhappiness of their heroes' lives. Their novels "The Stranger" (A. Camus) and "Nausea" (J.-P. Sartre) are considered to be the first classical examples of existentialist prose. This movement is the most fully represented in Ukrainian art by the works of writers of the 1920s and 1930s of the 20th century. (V. Pidmohylny, V. Domontovych, I. Bagryany, T. Osmachka, V. Barka, etc.). In literary criticism, reflections on the philosophical analysis of works of art are found in the works of M. Biletsky, D. Dontsov, S. Efremov, G. Kostyuk, S. Krymsky, S. Pavlychko, Y. Sherekh, and others. Obviously, within the current interdisciplinary research such a stream as "philosophy of literature" is up to date.

The ideas of European romanticism (as a philosophical-historical and cultural movement) were creatively rethought and assimilated even earlier, in the Romantic period of the emergence of new Ukrainian literature. It provided samples of highly artistic works, unique names of talented writers - creators and thinkers, who in their works reflected the philosophy of time.

Romanticism in the Ukrainian humanities from the point of view of philosophy, culturology, as well as at the intersection with literature, was studied by T. Bovsunivska, M. Bratasyuk, G. Verves, Y. Hrybkova, M. Zerov, S. Yefremov, N. Kalenichenko, S. Kozak, T. Komarynets, N. Krutykova, N. Mykhailovska, D. Nalyvayko, Y. Nakhlik, G. Nudha, I. Ogorodnyk, V. Ogorodnyk, E. Sverstyuk, A. Sinitsyna, D. Chyzhevsky, M. Yatsenko, E. Kyryliuk and others.

\section{Purpose}

The purpose of this study is to analyse the philosophical "literary-centric" model of Ukrainian Romanticism in terms of its polysemantic and diverse human dimension. Accordingly, the main tasks of the work are as follows: to determine the main features, the nature of Ukrainian Romanticism; to trace the main vectors of comprehension and image of man in the literature of this time; to outline the assimilation of the ideas of European philosophy inherent in this movement, as well as the special features of Ukrainian Romanticism, embodied in literary works.

In the work, we resorted to such methods as analysis and synthesis, comparative and interdisciplinary methods, as well as historical-comparative method, the principle of historicism.

\section{Statement of basic materials}

Ukrainian Romanticism is "literary-centric" inherently, because, due to the insufficient development of the actual philosophical doctrine, it is progressive writing that embodied the philosophy of time in the works of art, initiating a new period in the development of our literature in the late 18th - early 19th century. The literature works of Ukrainian authors are characterized by the set of features that are generally characteristic of the Romantic movement: irrationalism, lyricism (even if we talk about prose), the consonance of human existence with the existence of nature and national existence (appeal to folklore), reflection of feelings, idealization of human relations (resulting in emergence of a separate genre - idyll). But at the heart of these features there is a man, his or her life, character, daily routine, defeats and victories, sadness and joy. In the analysed period, the literature, its characters, approaches to their image change so much that T. Zhuzhgina-Allahverdian and S. Ostapenko (2020) propose to distinguish a separate branch in anthropological science - "Romantic anthropology", because, in their opinion, "the reflective man is represented by the Romantics not only in his "duality" and in the struggle with himself, but also in the diversity of relations with the world" (authors' transl.) (p. 166). M. Yatsenko aptly wrote about the human dimension of Romanticism: 
Given the unity of the macrocosm and the microcosm (of man), Romanticism placed man at the centre of the intersection of world forces and laws, inseparable from nature, society, destiny and God as an eternal life force. Because man is a part of the all-encompassing nature and, thus, contains cosmic forces, he appears individually-valuable and unique with the autonomous psychic world. His consciousness is not limited to the realm of the mind, as the enlighteners claimed; the inner essence of man goes beyond the sphere of practical thinking into the realm of feelings, intuition, imagination, fantasy, which make it possible to comprehend all the richness of being, its highest harmony. (authors' transl.) (Yatsenko, 2005, p. 235)

In the works of the period under study, as indicated, the features of existentialism are already visible. Obviously, we can talk about the existential features (sensitivity and sensibility) of Ukrainian literature, starting with the "philosophy of the heart" in the teachings and works of H. Skovoroda. Some signs of cordocentrism can be traced in the works of writers of the Romantic era - the first half of the 19th century. (M. Gogol, P. Kulish, Anna Barvinok, T. Shevchenko). P. Yurkevich and P. Kulish embodied this in their philosophical works. L. Nazarevych (2008) noted that "the existential worldview is spiritually close to the mentality of Ukrainians, so its penetration into the Ukrainian cultural space was natural" (authors' transl.) (p. 9). Apparently, this is why its features are so organic in the literature of that time. Such "natural", we can say, genetic for Ukrainians cordocentrism in its essence presupposes, on the one hand, a close connection with the national cultural tradition, and on the other - inevitably determines anthropological studies, as man in this doctrine becomes the centre of the universe.

The period of Romanticism is enriched by national features. National liberation movements in Central and Eastern Europe influence the crystallization of "I-natio" and "We-natio" in the people's minds. The assertion of one's own identity, the interaction of the individual with the national team became the "face" of Romanticism, including the Ukrainian one, because man, as a bearer of individual worldview, according to V. Havrylenko (2020), "occupies a central place in shaping of the collective worldview", which "can be presented as an integrated phenomenon, because it is based on a combination of common worldviews of individuals" (authors' transl.) (p. 74).

The appeal of writers and thinkers to folklore, as the most perfect form and origin of the author's work, and to the man of the people as its creator, promotes awareness of individuality, which, according to S. Krymsky (2003), "forms the highest instance of human self - personality" (p. 35). Through images, meanings, symbols, archetypal structures of folk art, romantics for the 
first time turn to the problem of depicting the features of national identity and national existence of man. Their works are written in the Ukrainian vernacular (serving as a basis for the literary language), which serves as the most powerful identifier of such ethnicity. Therefore, we can agree with the opinion of T. Bovsunivska (1997) that "in the formation of romantic art an exceptional role was played by the focus on imitating the folk spirit", and "this required a deep penetration into folk culture, free operation of conceptual categories of its natural state, so the romantics focus on the study of folk poetry as the only lasting source of folk spirit" (authors' transl.) (p. 104). This opinion can be confirmed by the words of M. Yatsenko, who noted:

Being in the centre of universal existence, man in Romanticism breaks

out of the prose of everyday life, the mercantile interests of society, be-

cause empirical material life does not exhaust the limitless possibilities of

existence. Real life, full of freedom and beauty, is in the sphere of spirit

and nature. (authors’ transl.) (Yatsenko, 2005, p. 236)

It is the desire of writers to convey this "folk spirit" that generated not only outstanding works, but also heroes, characters, real national "mega-images", such as Naum Drot (G. KvitkaOsnovyanenko "Marusya" - Ukrainian sentimentalism is believed to be a stage of preromanticism), Colonel Shram, Kirill Tur (P. Kulish "The Black Council") and others. Next to them there are characters from the lowest social strata of the population, who embody the features of the archetypes of the Wise Old (Man of God from P. Kulish's novel "The Black Council"; Perebendya from the poetry of the same name by T. Shevchenko; old man from the stories "Mermaid" and "Homebody" by Hanna Barvinok; a number of similar images from the prose by O. Storozhenko), Mother (Katerina, Hanna from the poems by T. Shevchenko "Katerina" and "Naimychka").

Literally all-encompassing appeal of romantics to folk art, ethnography can be traced in various forms of ethnic culture; it has become a kind of standard, model, touchstone of the nation. As T. Bovsunivska (1997) noted: "In the age of Romanticism, the requirement to culture to be ethnoculture, to radiate positive nation-building factors is openly set. The virtual meaning of romantic culture was reduced to the assistance of the ethnos in its formation and reduplication" (authors' transl.) (p. 89).

During this period, "populism" and the reflection of the folk penetrates into all spheres of culture, all branches of artistic and creative activity: painting, music, etc., not to mention ethnography and folklore, which are in the process of becoming ethnographic humanities. Against this background, the publications of records of folklore works are very noticeable - they are collections of dumas, songs, fairy tales, legends (M. Tserteliev, M. Maksimovich, A. Metlinsky, O. Bodiansky, P. Lukashevich, etc.). Regarding the latter, M. Yatsenko (2005) noted that "for romantics an unsurpassed example of "organic" poetry, higher than the literature of the educated classes, is folklore, which embodies the national spirit, national characteristics as a manifestation of the wealth of the universe" (authors' transl.) (p. 236). In this, at first glance, colourful, but unified process, writers try to use, accumulate all the mentioned potential of the means, creatively rethinking the people's existence and the existence of the individual in all its manifestations. Be- 
ing essentially a synthetic art, literary creativity due to its mental-verbal and written forms accumulates all the achievements of time and reflects the existence of the people from different points of view at the level of the literary text. Addressing the origins and interpretation of this process, R. Markiv stressed that it is marked by

The greatest dynamics in the most important moments of the historical existence of the people, during the intensified search for the appropriate spiritual continuum, deep ideological basis for further progress of the nation and the uniqueness of the national worldview, the expressiveness of ideological, philosophical, moral and ethical values. In such periods, the most developed forms of national or social consciousness are maximally consolidated in order to solve vital issues of the ethnos existence. (authors’ transl.) (Markiv, 2013, pp. 20-21)

Fine literature in the Romantic era is very close to folk one. Folklore receptions can be traced in the author's work at the level of stylistics, transformation of the poetics of lyrical or prose text, images, motives, even plots. This creates a new Ukrainian literary tradition, within which, along with folklore and together with it, the folk worldview and, in general, the cultural experience of the ethnos are accumulated, preserved and broadcast. The creative activity of romantics affirms the rootedness of man in his land (homeland), history, language, culture.

The mark of folk character as "the immanent quality of national writing, which testifies to the ethno-mental and historical essence of each nation, recorded in its language, culture, psychology" (Kovaliv, 2007, p. 99) in Romanticism determines the appeal to history (historicism) and understanding the role of man in history, because, as noted by T. Bovsunivska (2001), "history can be only national, nationality - only historical" (p. 223). It was at this stage that P. Kulish's first historical stories ("Martin Gak") and the first Ukrainian historical novel "The Black Council" by the same author (a very significant work for this period), T. Shevchenko's poems "Haidamaki", "Kavkaz", as well as other deeply historical works, appeared. A. Sinitsyna (2002) noted that "this evidenced a step from Enlightenment cosmopolitanism to the area of national history, to the study of national culture specifics, reproduction of the originality of a nation, its historical and local identity" (authors' transl.) (p. 36). Sometimes, deeply immersed in the philosophical and historical outline of the work and using the biographical method, we can determine a certain relationship between the author and his characters, or at least his attitude to them. P. Kulish's novel "The Black Council" can be very revealing here again. Similar features can be traced between the author of the work and a thoroughly romantic character - Kyrylo Tur. But this is far from a prototype. The writer sympathizes with all his characters, except Bryukhovetsky and Hvyntivka. As Y. Nakhlik noted in more detail: 
He partially sympathizes with the positions of the main characters (Shram and Somko, the Man of God and Kyrylo Tur, Petro and Lesia), but with no one - completely. The author balances between different vectors: historical (Shram, Somko), ironic-historical, and ironic-worldly (Kyrylo Tur), spiritual-existential (Man of God) and hamlet-idyllic, patriarchalfamily (Petro, Lesia), giving preference to none of them. (authors’ transl.) (Nakhlik, 2007, p. 117)

Characters of the novel, such as Hetman Somko and Colonel Shram, represent the state line (the role of the individual in history) in the novel, embodying the historical perspective of Ukraine. However, according to the final of the Nizhyn Council in 1663, this prospect remains unknown. Therefore, these heroes die, showing their successors a worthy example of how to fight for their land and state. At the forefront here, there is the so-called "farm" philosophy of P. Kulish, his idea of the archetypal "Hamlet-Home", which is embodied by Cherevan and his family. The priority of the constants "Home" and "Family" for the Ukrainian mentality and cultural tradition is confirmed by the ending of the novel, where the family idyll defines the patriarchal family as one of the greatest spiritual values of the people.

The image of the Man of God (kobzar) in P. Kulish's novel is both interesting and complex in terms of traditional features. On the one hand, it is thoroughly traditional, and on the other - "his image seems to demonstrate some resistance to this tradition by gaining a different, deeply philosophical meaning" (authors' transl.) (Yankovska, 2016, p. 324). The kobzar should be abstracted from political events by his blindness, however, walking "without a guide", he "sees" and knows more than others, gives sound advice, is aware of everything that happens among the Cossacks, rejoices, including with "his songs". He "seems to be a minor character, but he is not perceived at all as an artistic detail or a "background" image, a certain "decoration of time" or "filling of space". He appears where and when he is needed" (Yankovska, 2016, p. 324), which allows us to see the archetype of the Wise Old Man in him. The existentiality and transcendence of the Man of God vergers on "cosmopolitanism", but still he remains a unique character, deeply national in his time and space.

Thus, as an example, we have a completely different reading of the work, based on modern approaches to its analysis, a combination of multidisciplinary analysis, during which we can say, according to P. Ivanyshyn (2008), about "interpretation" and "reinterpretation" of texts (pp. 5-6). Bearing in mind the interpretation, the author relies on the judgment of H.-G. Gadamer, about the fact that the "historical life of the transmission [...] is precisely the need for more and more new assimilations and interpretations". Regarding reinterpretation, he emphasizes that "the urgent need for interpretation arises when the semantic content of the recorded is controversial, and it is necessary to achieve a correct understanding of the message" (authors' transl.) (Ivanyshyn, 2008, p. 56). In this regard, the judgment of S. Kvit (2011) is also very correct, who noted: "Each new reading of a certain style in a different way actualizes for us the meaning of the work, giving it relevance and a new contextual sound" (authors' transl.) (pp. 94-95). In fact, such a reading of the work is carried out at 
the intersection of such humanities as philosophical and literary hermeneutics, as a result of which it becomes possible to decipher the philosophical views of the time by the literary text.

The complexity of Romanticism (especially in Ukraine) lies in the instability and diversity of philosophical views, the same affinity with the literary process, which is characterized by heterogeneity and synthesis of movements, styles, trends, groups, schools, search for a new word and method. T. Rudenko (2010) noted that "man for romantics is the greatest secret, a combination of diverse principles, the confrontation of which forms and develops the personality". According to the scientist, "romantics were the first to look at a person through the prism of his hidden desires, dreams, aspirations and ideals" (authors' transl.) (p. 65). This influenced in general the change of the essential basis and poetics of literary creativity.

Obviously, in the era of Romanticism, it is worth paying attention to the personality of an author, a writer, who, using the means of artistic creativity, transmitted the philosophy of time. In this regard, we can rely on the words of N. Kopystianska (2012), who noted: "Every era, every artistic direction, trend has a basis in the development of the philosophy of time and at the same time artists become co-creators of this basis, often its founders" (authors' transl.) (p. 35), which is especially evident in the analysed period, when the Ukrainian intelligentsia had to fight and prove the right to the existence of their language, culture, national identity. M. Skrynnyk (2008) emphasized that in this period, "according to the texts of Ukrainian romantics, individual identity is rooted in the national meta-narrative" (authors' transl.) (p. 4).

\section{Originality}

Studies that reflect the main features of Romanticism (as a philosophical movement), which were embodied in the literary works of writers of the 18th - mid-19th century, mostly refer to the study of European literary tradition. Since Ukrainian Romanticism is basically purely "literarycentric", has its own features and vectors of formation and development, the novelty of this study is not only in selection and generalization of these features, but also in understanding the place of man in national philosophy and literature of this period.

\section{Conclusions}

Thus, we can state that a man in the work and philosophy of the Romantics appears as a person who, realizing the temporality of his or her own existence, reflecting on the meaning of it, tries to find its spiritual meaning. Therein he or she sees the justification of his or her own life, the meaning of which is in axiological certainty. The main values in human life (apart from life as "self-worth") are the existentials of truth, goodness, freedom, love, honour, family. Failures to achieve them lead to suffering. It is through the "living through" these existentials that the individual is realized as a person. In self-affirmation, man in the philosophy and work of the Romantics goes through certain stages of "spiritual evolution", which are his or her choice. On the other hand, there is destiny (fate) and faith as constants, "what is given", "predetermined", which is often taken into account by the individual in the process of self-development. The writers saw in man a harmonious combination of natural and social, through which the person carries out his or her own national existence. In addition to the objective realities of the external world, in their works, Romantic writers appeal to the subjective, internal, spiritual, "ideal" world of the hero, who interacts with objective reality through his own system of values. At each level of development of the humanities and methodology of cognition, this allows for a different, new interpretation of these works. Retaining the national code as such, they remain relevant to this day. 


\section{REFERENCES}

Bohutskyi, Y. P., Andrushchenko, V. P., Bezvershuk, Z. O., \& Novokhatko, L. M. (2007). Ukrainska kultura v yevropeiskomu konteksti. Kyiv: Znannia. (in Ukrainian)

Bovsunivska, T. (1997). Etnohenez i teohenez. In Fenomen ukrainskoho romantyzmu (Pt. 1). Kyiv: IL NANU. (in Ukrainian)

Bovsunivska, T. V. (2001). Istoriia ukrainskoi estetyky pershoi polovyny XIX stolittia. Kyiv: Vydavnychyi Dim "Buraho". (in Ukrainian)

Busch, W. (1999). Klassizismus, Romantik und Historismus: Einführung. Kunsthistorische Arbeitsblätter, 1, 39-48. DOI: https://doi.org/10.11588/artdok.00001799 (in German)

Havrylenko, V. V. (2020). Human as a carrier of the worldview: Individual and collective dimensions. Anthropological Measurements of Philosophical Research, 18, 62-75. DOI: https://doi.org/10.15802/ ampr.v0i18.210988 (in Ukrainian)

Ivanyshyn, P. (2008). Natsionalnyi sposib rozuminnia v poezii T. Shevchenka, Ye. Malaniuka, L. Kostenko. Kyiv: Akademvydav. (in Ukrainian)

Kopystianska, N. (2012). Chas i prostir u mystetstvi slova. Lviv: PAIS. (in Ukrainian)

Kovaliv, Y. I. (2007). Literaturoznavcha entsyklopediia (Vol. 2). Kyiv: VTs "Akademiia". (in Ukrainian)

Krymsky, S. (2003). Zapyty filosofskykh smysliv. Kyiv: PARAPAN. (in Ukrainian)

Kvit, S. (2011). Hermenevtyka styliu. Kyiv: Vydavnychyi dim "Kyievo-Mohylianska akademiia". (in Ukrainian)

Malyshivska, I. V., \& Trotsenko, O. Y. (2018). Existentialist model of reality in the works of ukrainian writers of the early 20th century. Precarpathian Bulletin of the Shevchenko Scientific Society Word, 4(48), 222-232. (in Ukrainian)

Markiv, R. (2013). Folklor i literatura: Formy dialohu (Folkloryzm v ukrainskii literaturi kintsia XIX-pochatku XX stolittia). Lviv: PAIS. (in Ukrainian)

Nakhlik, Y. (2007). Svitohliad i tvorchist Panteleimona Kulisha. In Panteleimon Kulish: Osobystist, pysmennyk, myslytel (Vol. 2). Kyiv: Ukrainskyi pysmennyk. (in Ukrainian)

Nazarevych, L. T. (2008). Existentialism as philosophical and artistic aesthetic dominant idea of Ukrainian small prose of the late 19th - the early 20th century (Dissertation thesis for obtaining the scientific degree of the Candidate of Philology). Ternopil Volodymyr Hnatiuk National Pedagogical University, Ternopil. (in Ukrainian)

Rudenko, T. P. (2010). Osobystist u khudozhnii tvorchosti romantyzmu. Vzaiemozv’iazok filosofii i literatury. Visnyk of National Technical University of Ukraine "Kyiv Polytechnic Institute". Philosophy. Psychology. Pedagogics, 3, 65-69. (in Ukrainian)

Sinitsyna, A. (2002). Istoryko-filosofski idei ukrainskoho romantyzmu (Panteleimon Kulish, Mykola Kostomarov). Lviv: LNB im. V. Stefanyka NAN Ukrainy. (in Ukrainian)

Skrynnyk, M. A. (2008). Existential senses of national identity in Ukrainian romanticism (Dissertation thesis for obtaining the scientific degree of the Doctor of Philosophy). Ivan Franko National University of Lviv, Lviv. (in Ukrainian)

Stetsenko, V. (2010). Existentialism as "the philosophy of a man" of the $20^{\text {th }}$ century. Socio-humanitarian Problems of Person, 4, 44-54. (in Ukrainian)

Yankovska, Z. (2016). Folkloryzm ukrainskoi romantychnoi prozy. Lviv: NVF "Ukrainski tekhnolohii". (in Ukrainian)

Yatsenko, M. T. (2005). Romantyzm. In Istoriia ukrainskoi literatury XIX stolittia (Vol. 1, pp.230-285). Kyiv: Lybid. (in Ukrainian)

Zhuzhgina-Allahverdian, T. N., \& Ostapenko, S. A. (2020). Romantic human study: Peculiarities of personality philosophy in the literature of the 1820-1830-ies. Anthropological Measurements of Philosophical Research, 18, 155-167. DOI: https://doi.org/10.15802/ampr.v0i18.221425 (in Ukrainian)

\section{LIST OF REFERENCE LINKS}

Богуцький Ю. П., Андрущенко В. П., Безвершук Ж. О., Новохатько Л. М. Украӥнська культура в європейському контексті. Київ : Знання, 2007. 679 с.

Бовсунівська Т. Феномен украӥнського романтизму. Ч. 1: Етногенез і теогенез. Київ : ІЛ НАНУ, 1997.154 с.

Бовсунівська Т. В. Історія украӥнської естетики периої половини ХІХ століття. Київ : Видавничий Дім "Бураго", 2001. 344 с. 
Busch, W. Klassizismus, Romantik und Historismus: Einführung. Kunsthistorische Arbeitsblätter. 1999. Heft 1. S. 39-48. DOI: https://doi.org/10.11588/artdok.00001799

Havrylenko V. V. Human as a carrier of the worldview: individual and collective dimensions. Anthropological Measurements of Philosophical Research. 2020. No. 18. P. 62-75. DOI: https://doi.org/10.15802/ ampr.v0i18.210988

Іванишин П. Національний спосіб розуміння в поезї Т. Шевченка, С. Маланюка, Л. Костенко. Київ : Академвидав, 2008. 392 с.

Копистянська Н. Час і простір у мистецтві слова. Львів : ПАІС, 2012. 344 с.

Літературознавча енциклопедія : у 2 т. / автор-укл. Ю. І. Ковалів. Київ : ВЦ "Академія", 2007. Т. 2. 624 с.

Кримський С. Запити філософських смислів. Київ : ПАРАПАН, 2003. 240 с.

Квіт С. Герменевтика стилю. Київ : Видавничий дім "Києво-Могилянська академія", 2011. 143 с.

Малишівська I. В., Троценко О. Я. Екзистенціалістська модель дійсності у творах українських письменників початку ХХ століття. Прикарпатський вісник НТШ Слово. 2018. № 4 (48). С. 222-232.

Марків Р. Фольклор і література: форми діалогу (Фольклоризм в украӥнській літературі кіния XIX - початку ХХ століття). Львів : ПАІС, 2013. 288 с.

Нахлік Є. Пантелеймон Куліш: особистість, письменник, мислитель : у 2 т. Т. 2: Світогляд і творчість Пантелеймона Куліша. Київ : Український письменник, 2007. 462 с.

Назаревич Л. Т. Екзистениійність як філософська та художньо-естетична домінанта української малої прози кіния XIX - початку XX століття : автореф. дис. ... канд. філол. наук. Терноп. нац. пед. ун-т ім. В. Гнатюка. Тернопіль, 2008. 20 с.

Руденко Т. П. Особистість у художній творчості романтизму. Взаємозв'язок філософії і літератури. Вісник НТУУ "КПI". Філософія. Психологія. Педагогіка. 2010. Вип. 3. С. 65-69.

Сініцина А. Історико-філософські ідеї украӥнського романтизму (Пантелеймон Куліш, Микола Костомаров). Львів : ЛНБ ім. В. Стефаника НАН України, 2002. 160 с.

Скринник М. А. Буттєві смисли національної ідентичності в українському романтизмі : автореф. дис. ... д-ра філос. наук. Львів. нац. ун-т ім. І. Франка. Львів, 2008. 39 с.

Стеценко В. Екзистенціалізм як "філософія людини" ХХ сторіччя. Соціогуманітарні проблеми людини. 2010. № 4. C. 44-54.

Янковська Ж. Фольклоризм української романтичної прози. Львів : НВФ "Українські технології", 2016. $610 \mathrm{c}$.

Яценко М. Т. Романтизм. Історія украӥнської літератури ХІХ століття. Київ : Либідь, 2005. Т. 1. С. $230-285$.

Zhuzhgina-Allahverdian T. N., Ostapenko S. A. Romantic human study: peculiarities of personality philosophy in the literature of the 1820-1830-ies. Anthropological Measurements of Philosophical Research. 2020. No. 18. P. 155-167. DOI: https://doi.org/10.15802/ampr.v0i18.221425

\section{Ж. О. ЯНКОВСЬКА ${ }^{1^{*}}$, Л. В. СОРОЧУК ${ }^{2 *}$}

\footnotetext{
${ }^{1 *}$ Національний університет "Острозька академія" (Острог, Україна), ел. пошта zanna.malva@gmail.com, ORCID 0000-0002-7846-2796

2*Київський національний університет імені Тараса Шевченка (Київ, Україна), ел. пошта LVS1166@ukr.net, ORCID 0000-0003-0478-356X
}

\section{Антропологічний вимір філософської "літературоцентричної" моделі українського романтизму}

Мета. Романтизм як напрям розвинувся в Німеччині, звідки, ставши у XVIII-XIX ст. філософією часу, поширився в усі країни Свропи. "Рухомість" романтичної доктрини, iї різноманітність, іноді суперечливість поглядів, ставлення до людини як вільної, гармонійної, творчої особистості зумовили сприйнятливість цього напряму етносами, відмінними за своїм характером і ментальністю. Його ідеї знайшли широкий відгук в Україні з їі "кордоцентричним" типом культури саме на початку ХІХ ст. Оскільки особливістю "українського романтизму" був його "літературоцентричний" характер, то мета цього дослідження - проаналізувати та осмислити місце людини в національній філософії й літературі зазначеного періоду. Відповідно, головними завданнями праці є: визначити основні ознаки, характер українського романтизму; простежити головні вектори осмислення й зображення людини в літературі цього часу. Теоретичний базис. Ідеї європейського ро-

Creative Commons Attribution 4.0 International doi: https://doi.org/10.15802/ampr.v0i19.236062 
мантизму (як філософсько-історичного й загальнокультурного напряму) були творчо переосмислені й засвоєні в період постання нової української літератури. Вона надала зразки високохудожніх творів, непересічні імена талановитих письменників - творців і мислителів, які у своїх працях відобразили філософію часу. Спираючись на праці Ф. Шлегеля, частково Е. Гусерля, М. Гайдеггера, К. Ясперса, романтизм в українській гуманітаристиці з точки зору філософії, культурології, а також на перетині з літературою вивчали Т. Бовсунівська, Ю. Грибкова, С. Єфремов, Н. Калениченко, С. Козак, Т. Комаринець, Д. Наливайко, О. Нахлік, І. Огородник, В. Огородник, А. Сініцина, Д. Чижевський, М. Яценко, Є. Кирилюк, М. Білецький, Д. Донцов, С. Сфремов, Г. Костюк, С. Кримський, Ю. Шерех та ін. Наукова новизна. Авторами статті доведено, що романтизм в Україні, будучи в своїй основі "літературоцентричним", увібравши головні ідеї й ознаки європейського романтизму, має власні ознаки й вектори становлення та розвитку. Людина в такому різновиді напряму, завдяки засобам художності, постає дуже виразно, як духовно багата, чутлива, вразлива й сильна особистість. Для неї найвищою цінністю є свобода, здатність вільно приймати самостійні доленосні рішення. Висновки. Українські письменники, відображаючи філософські ідеї романтизму, вбачали у людині гармонійне поєднання "природного" та "соціального", через які опосередковано вона й здійснює власне національне буття. Окрім об’єктивних реалій зовнішнього світу, у своїх творах письменники-романтики апелюють до суб'єктивного, внутрішнього, духовного, "ідеального" світу героя, що взаємодіє з реальністю за допомогою власної системи цінностей. На кожному рівні розвитку гуманітарних наук і методології пізнання це дає можливість нового прочитання цих творів.

Ключові слова: людина; особистість; духовність; романтизм; "літературоцентрична" модель українського романтизму; свобода

Received: 14.01.2021

Accepted: 28.05.2021 